A construção do campo

\section{MARIA APARECIDA}

BACCEGA é professoraassociada da ECA-USP,

editora da revista

Comunicação e Educação e autora de, entre outros,

Comunicação e

Linguagem: Discursos e

Ciência (Moderna). 


\section{comunicação/educação: alguns caminhos}

Evidencia-se, hoje, uma grande disputa entre os meios de comunicação, de um lado, e as tradicionais agências de socialização - escola e família -, de outro. Ambos os lados pretendem ter a hegemonia na influência da formação de valores, na condução do imaginário e dos procedimentos dos indivíduos/sujeitos.

Esse conjunto de relações que se estabelecem no imaginário de uma dada cultura, de um determinado grupo, é uma construção coletiva, na qual se baseia a memória social daquele grupo, e a qual a comunidade procura manter. Essa memória coletiva é que vai respaldar o modo que os indivíduos/sujeitos se vêem no confronto com o outro, a ação deles em relação aos demais e em relação às instituições. As relações imagéticas têm como base os corpos físicos. "Todo corpo físico pode ser percebido como símbolo [...]. E toda imagem artístico-simbólica ocasionada por um objeto físico particular já é um produto ideológico. Converte-se, assim, em signo o objeto físico, o qual, sem deixar de fazer parte da realidade material, passa a refletir e a refratar, numa certa medida, uma outra realidade" (I). 
É nesse âmbito de ficção/realidade que a disputa se institui, que a busca da hegemonia se dá. Aí se constrói o campo da comunicação/educação.

Nesse campo se constroem sentidos novos, renovados, ou ratificam-se mesmos sentidos com roupagens novas, sempre inter-relacionados à dinâmica da sociedade, lugar último e primeiro onde os sentidos verdadeiramente se constroem.

A sociedade funciona no bojo de um número infindável de discursos que se cruzam, se esbarram, se anulam, se complementam: dessa dinâmica nascem os novos discursos, os quais ajudam a alterar os significados dos outros e vão alterando seus próprios significados, nos momentos em que a materialidade do discurso-texto que circula é captada pelo enunciatário/receptor. Este lê/interpreta os discursos a partir do diálogo com os demais discursos sociais. Essa dinâmica ocorre tanto em nível sincrônico como diacrônico. As permanências históricas, muitas vezes sob a forma de mitos, provérbios, estereótipos, valores "positivos" ou "negativos", também constituem parte importante desse diálogo entre os discursos.

O universo de cada indivíduo é formado pelo diálogo desses discursos, nos quais seu cotidiano está inserido. Eé a partir dessa materialidade discursiva que se constitui a subjetividade. Logo, a subjetividade nada mais é que o resultado da polifonia que cada indivíduo carrega.

\section{O CAMPO DA COMUNICAC̦ÃO}

O campo da comunicação constitui-se a partir de uma multiplicidade de discursos que originam e configuram a unicidade do discurso da comunicação. O comunicador é o indivíduo/sujeito que o assume. Enunciador/enunciatário de todos os discursos em constante embate na sociedade, ele é o mediador da informação coletiva.

Se, por um lado, o comunicador tem a condição de enunciador de um discurso específico, ao produzi-lo ele estará, na verda- de, reelaborando a pluralidade de discursos que recebe: ou seja, estará na condição de enunciatário. Ele é, portanto, enunciador/enunciatário.

O mesmo ocorre com o indivíduo/sujeito ao qual se destina o produto: enunciatário do discurso da comunicação, este indivíduo/sujeito é também enunciatário de todos os outros discursos sociais que circulam no seu universo, os quais ele mobiliza no processo da leitura/interpretação. Como a comunicação só se efetiva quando ela é apropriada e se torna fonte de outro discurso, na condição de enunciatário está presente a condição de enunciador. Ele é, portanto enunciatário/ enunciador.

Um dos desafios está contido nessa dinâmica: o campo da comunicação constitui-se de dois pólos básicos, que se intercambiam - de um lado, enunciador/ enunciatário e, de outro, enunciatário/ enunciador.

Tendo que incorporar o discurso dos vários outros que é, cada um, resultado dos vários outros universos, compete ao discurso da comunicação procurar os "fios ideológicos" (expressão de Bakhtin) com os quais conduzirá a inter-relação entre eles, tecendo-se. Sua trama implica a dialogicidade, presente na polifonia, numa manifestação das relações macroestruturais com a vida cotidiana.

O eu plural deve tornar-se claro e manifestar essa clareza para o outro; fazer aflorar a importância dos indivíduos/sujeitos de ambos os pólos, na configuração das verdades, dos valores que permeiam o imaginário, dos comportamentos que estão presentes no cotidiano das pessoas, dos grupos, das classes sociais. São essas verdades, valores e comportamentos que, formando a consciência social, ideológica e estética, vão atualizar as manifestações dos produtos da indústria cultural.

O estudo desse campo incorpora os resultados das ciências, sobretudo as sociais. No processo mesmo de incorporação, temos um primeiro momento de metassignificação, uma vez que cada ciência se desloca de seu domínio de origem, 
com suas configurações, e passa a fazer parte de um outro. Mas há outros processos, configurando outros níveis de metassignificação: ao compor o novo campo, cada ciência vai encontrar-se com outras que também aí figuram nas mesmas condições, ou seja, na condição de metassignificação, e vai dialogar com elas, reconstruindo-se, cada uma delas, nessa interdiscursividade. A interdiscursividade implica o diálogo com os outros discursos, ao mesmo tempo que revela a especificidade do discurso construído nesse processo.

A Sociologia, a História, a Filosofia, a Linguagem, etc. ganham outra especificidade no diálogo interdiscursivo. Essa especificidade será, agora, não mais a que se prende ao domínio de onde provêm, mas aquela que, no confronto de cada ciência com as demais, permite-lhe distinguir-se.

Desse modo, a apropriação das ciências sociais para a constituição desse campo se dá num processo espiralado de metassignificações, que redundam, obviamente, em novas posturas metodológicas, a partir das quais se poderá dar conta da efetividade dos processos comunicacionais.

\section{O CAMPO COMUNICACÃO/ EDUCACÃAO}

Aí está a base da construção do campo comunicação/educação como novo espaço teórico capaz de fundamentar práticas de formação de sujeitos conscientes. Trata-se de tarefa complexa, que exige o reconhecimento dos meios de comunicação como um outro lugar do saber, atuando juntamente com a escola e outras agências de socialização.

O encontro comunicação/educação leva a nova metassignificação, ressemantizando os sentidos, exigindo, cada vez mais, a capacidade de pensar criticamente a realidade, de conseguir selecionar informação (disponível em número cada vez maior graças à tecnologia, Internet, por exemplo) e de inter-relacionar conhecimentos.
O desafio, hoje, é a interpretação do mundo em que vivemos, uma vez que as relações imagéticas estão carregadas da presença da mídia. Trata-se de um mundo construído pelos meios de comunicação, que selecionam o que devemos conhecer, os temas a serem pautados para discussão e, mais que isso, o ponto de vista a partir do qual vamos compreender esses temas. Eles se constituem em educadores privilegiados, dividindo as funções antes destinadas à escola. E têm levado vantagem.

O campo da comunicação/educação é um dos desafios maiores da contemporaneidade. Não se reduz a fragmentos, como a eterna discussão sobre a adequação da utilização das tecnologias no âmbito escolar, quer em escolas com aparato tecnológico de primeira linha quer nas escolas de "pés no chão", tendo em vista que a edição do mundo realizada pelos meios está presente em alunos, professores, cidadãos. Sua complexidade obriga a inclusão de temas como mediações, criticidade, informação e conhecimento, circulação das formas simbólicas, ressignificação da escola e do professor, recepção, entre muitos outros.

\section{DO MUNDO EDITADO À CONSTRUÇÃO DO MUNDO}

Hoje, o mundo é trazido até o horizonte de nossa percepção, até o universo de nosso conhecimento. Como não podemos estar presentes em todos os acontecimentos, em todos os lugares, temos que confiar nos relatos. O mundo que nos é trazido pelos relatos, que assim conhecemos e a partir do qual refletimos, é um mundo que nos chega editado, ou seja, ele é redesenhado num trajeto que passa por centenas, às vezes milhares de mediações, até que se manifeste no rádio, na televisão, no jornal. Ou na fala do vizinho e nas conversas dos alunos.

São essas mediações - instituições e pessoas - que selecionam o que vamos ouvir, ver ou ler; que fazem a montagem do mundo que conhecemos. 
Aqui está um dos pontos básicos da reflexão sobre o espaço onde se encontram comunicação e educação: que o mundo é editado e assim ele chega a todos nós; que sua edição obedece a interesses de diferentes tipos, sobretudo econômicos, e que, desse modo, acabamos por perceber até a nossa própria realidade do jeito que ela foi editada.

Editar é, portanto, construir uma realidade outra, a partir de supressões ou acréscimos em um acontecimento. Ou, muitas vezes, apenas pelo destaque de uma parte do fato em detrimento de outra.

Editar é reconfigurar alguma coisa, dando-lhe novo significado, atendendo a determinado interesse, buscando um determinado objetivo, fazendo valer um determinado ponto de vista.

Essa realidade outra que a edição constrói reconfigura-se no enunciatário/receptor, com seu universo cultural e dinâmica próprios. Esse é o percurso da comunicação, desde a mais democrática, a que usa apenas o suporte do aparelho fonador, até aquela que a tecnologia possibilita: o relato, em tempo real, de fatos (escolhidos entre muitos) que acontecem em espaços distantes, na Terra ou no espaço.

Se o mundo a que temos acesso é este, o editado, é nele, com ele e para ele que se impõe construir a cidadania. O desafio, então, é como trabalhar esse mundo editado, presente no cotidiano, que penetra ardilosamente em nossas decisões e que, pela persuasão que o caracteriza, assume o lugar de "verdade" única.

Eis outro ponto importante no processo de reflexão sobre o campo comunicação/educação: já não se trata mais de discutir se devemos ou não usar os meios no processo educacional ou de procurar estratégias de educação para os meios; trata-se de constatar que eles são os educadores primeiros, pelos quais passa a construção da cidadania. É desse lugar que devemos nos relacionar com eles. Eé esse o lugar onde temos que esclarecer qual cidadania nos interessa.

Afinal, são eles a fonte primeira que educa a todos os educadores: pais, profes- sores, agentes de comunidade, etc. Precisamos procurar entendê-los bem, saber ler criticamente os meios de comunicação, para conseguirmos percorrer o trajeto que vai do mundo que nos entregam pronto, editado, à construção do mundo que permite a todos o pleno exercício da cidadania.

Essa cultura da mídia se manifesta em um conjunto articulado e diversificado de produtos (pólodo enunciador/emissor) que entram em relação com o conjunto articulado e diversificado de vivências do enunciatário/receptor, cujo universo de valores, posto em movimento, ativa os significados dos produtos. Na verdade, a cultura da mídia não está no enunciador/emissor, não está no enunciatário/receptor: está no território que se cria nesse encontro, gerando significados particulares, que, se contêm interseção com cada um dos pólos, não se limitam a nenhum deles. Caso contrário, a mídia seria apenas veículo de significados e não construtora de significados. Sua complexidade reside exatamente no fato de, construindo significados no território que inclui cada um dos pólos - enunciador/emissor - enunciatário/receptor -, ela exigir permanentemente a dialética entre o já visto e o por ver, ou seja, a novidade que responde pelas e alimenta as mudanças contínuas de identidade versus a estabilidade que cada grupo social busca em sua dinâmica. O único limite é o horizonte da formação social na qual estão e que inclui tanto o já manifesto quanto o ainda virtualmente contido como possibilidades a serem realizadas.

Por essas e incontáveis outras razões, podemos perceber como é fundamental a construção do campo comunicação/educação. Ele inclui - mas não se resume a educação para os meios, leitura crítica dos meios, uso da tecnologia em sala de aula, formação do professor para o trato com os meios, etc. Ele se rege, sobretudo, pela construção da cidadania, pela inserção neste mundo editado, com o qual todos convivemos, no qual todos vivemos e que queremos modificar.

O campo comunicação/educação constrói-se num movimento que percorre o todo 
e as partes, em intercâmbio permanente. Ou seja: do território digital à arte-educação, de meio ambiente à educação a distância, entre muitos outros tópicos, sem esquecer os vários suportes, as várias linguagens - televisão, rádio, teatro, cinema, jornal, etc. Tudo percorrido com olhos da congregação dessas agências de formação: a escola e os meios, sempre no sentido da construção da cidadania.

\section{CENÁRIOS: DA INFORMAÇÃO AO CONHECIMENTO}

Cada época vivida pela humanidade tem características próprias, apresentando, dialeticamente, aspectos positivos e negativos.

As distinções entre as épocas podem ser marcadas, entre outros aspectos, pela formação e expansão dos mercados, que determinou pólos de concentração, baseados na busca permanente de acumulação do capital. Otávio Ianni, em "As Economiasmundo", aponta as diversidades e desigualdades com as quais cada totalidade se constitui. Segundo o autor, cada época

"é um todo em movimento, heterogêneo, integrado, tenso e antagônico. É sempre problemático, atravessado pelos movimentos de integração e fragmentação. Suas partes, compreendendo nações e nacionalidades, grupos e classes sociais, movimentos sociais e partidos políticos, conjugamse de modo desigual, articulado e tenso, no âmbito do todo. Simultaneamente, esse todo confere outros e novos significados e movimentos às partes. Anulam-se e multiplicam-se os espaços e os tempos, já que se trata de uma totalidade heterogênea, contraditória, viva, em movimento" (2).

Fredric Jameson aponta três períodos de expansão capitalista, caracterizados por rupturas “tecnológicas”. Segundo ele,

"houve três momentos fundamentais no capitalismo, cada um marcando uma expansão dialética com relação ao estágio anterior. O capitalismo de mercado, o estágio do monopólio ou do imperialismo, e o nosso, erroneamente chamado de pós-industrial, mas que poderia ser mais bem designado como o do capital multinacional. [...] Esse capitalismo tardio, ou multinacional, ou de consumo, longe de ser inconsistente com a grande análise do século XIX de Marx, constitui, ao contrário, a mais pura forma de capital que jamais existiu, uma prodigiosa expansão do capital que atinge áreas até então fora do mercado".

Nessa fase, segundo o autor, deve-se ressaltar, a "ascensão das mídias e da indústria da propaganda" (3).

Resultado da fase contemporânea do capital, a cultura manifesta fragmentaçãoe globalização num processo de complementação que se dá no âmbito do mercado. Como lembra Martín-Barbero (4), o global é o espaço novo produzido pelo mercado e pelas tecnologias, que dependem dele para sua permanente expansão.

O mundo, que sempre esteve em permanente mudança, hoje tem altamente multiplicada a rapidez dessas mudanças, devido ao avanço das tecnologias. É esse o cenário que possibilita o fortalecimento das corporações internacionais e consequiente ruptura das fronteiras nacionais, atingindo "áreas até então fora do mercado".

Essa realidade tem como sustentáculo os meios de comunicação, mediadores privilegiados entre nós e o mundo, e que cumprem o papel de costurar as diferentes realidades. São os meios de comunicação que divulgam, em escala mundial, informações (fragmentadas) hoje tomadas como conhecimento, construindo, desse modo, o mundo que conhecemos. Trata-se, na verdade, do processo metonímico - a parte escolhida para ser divulgada, para ser conhecida, vale pelo todo. É como se "o mundo todo" fosse constituído apenas por aqueles fatos/ notícias que chegam até nós.

Consideramos, porém, que informação não é conhecimento. Poderá até ser um passo importante. O conhecimento impli-

\footnotetext{
2 Otávio lanni, "As Economiasmundo", in Teorias da Globo lização, Rio de Janeiro, Civil zação Brasileira, 1995, p. 43

3 Fredric Jameson, "A Lógica Cultural do Capitalismo Tar dio", in Pós-modernismo. A Lógica Cultural do Capitalismo Tardio, trad. Maria Elisa Velasco, São Paulo, Ática 1996, p. 61

4 Jesus Martín-Barbero, "La Comunicación Plural: Alteridad y Socialidad", in Dia-logos 40 set. de 1994, pp. 73-9.
} 
ca crítica. Ele se baseia na inter-relação e não na fragmentação. Todos temos observado que essa troca do conhecimento pela informação tem resultado numa diminuição da criticidade.

O conhecimento é um processo que prevê a condição de reelaborar o que vem como um “dado", possibilitando que não sejamos meros reprodutores; inclui a capacidade de elaborações novas, permitindo reconhecer, trazer à superfície o que ainda é virtual, o que, na sociedade, está ainda maldesenhado, com contornos borrados. Para tanto, o conhecimento prevê a construção de uma visão que totalize os fatos, inter-relacionando todas as esferas da sociedade, percebendo que o que está acontecendo em cada uma delas é resultado da dinâmica que faz com que todas interajam, dentro das possibilidades daquela formação social, naquele momento histórico; permite perceber, enfim, que os diversos fenômenos da vida social estabelecem suas relações tendo como referência a sociedade como um todo. Para tanto, podemos perceber, as informações - fragmentadas não são suficientes.

Os meios de comunicação, sobretudo a televisão, ao produzirem essas informações, transformam em verdadeiros espetáculos os acontecimentos selecionados para se tornarem notícias. Já na década de 60, Guy Debord percebia "na vida contemporânea uma 'sociedade de espetáculo', em que a forma mais desenvolvida de mercadoria era antes a imagem do que o produto material concreto", e que, "na segunda metade do século XX, a imagem substituiria a estrada de ferro e o automóvel como força motriz da economia" (5).

Por sua condição de "espetáculo", parece que o mais importante na informação passa a ser aquilo que ela tem de atração, de entretenimento. A informação, que parece ocupar o lugar desse conhecimento, tornou-se, ela própria, a base para a reprodução do sistema, uma mercadoria a mais em circulação nessa totalidade. A confusão entre conhecimento e informação, entre totalidade e fragmentação, leva à concepção de que a informação veiculada pelos meios é suficiente para a formação do cidadão. Na verdade, o conhecimento continua a ser condição indispensável para a crítica.

\section{RESSIGNIFICAÇ̃O DA ESCOLA: a IIRCULAÇ̃̃O DA IDEOLOGIA}

A presença, em maior ou menor intensidade de acordo com a classe social, da tecnologia na sociedade, e particularmente na escola, é constatável. Dados recentes indicam que existem hoje sete milhões de usuários da Internet em toda a América Latina, dos quais quatro milhões no Brasil. Prevê-se que serão 34 milhões até o fim do ano 2000 (6). Além disso, é preciso lembrar, entre outros, as grandes redes internacionais de televisão, o alcance do rádio, a velocidade da divulgação das informações selecionadas pelas agências internacionais de notícias. Tudo isso pede uma reflexão sobre as representações, os valores, a ideologia que circulam na rede e influenciam os novos sujeitos que resultam dessa realidade e que trabalham, em conjunto, na instituição escolar, sejam professores, alunos, funcionários, pais e outros interessados. Todos eles se congregam em torno de objetivos comuns. São todos participantes de uma dada realidade social, caracterizada por uma ideologia. “A ideologia é uma das formas de práxis social: aquela que, partindo da experiência imediata dos dados da vida social, constrói abstratamente um sistema de idéias ou representações sobre a realidade" (7).

A sociedade que forma nossos alunos e nos forma produz as representações, as formas simbólicas pelas quais se rege, que se transformam em bens simbólicos no processo de circulação, o qual se dá de acordo com as características da formação socioeconômica. Aliás, as formas simbólicas são próprias do ser humano: a língua, criação que facultou ao homem projetar, é um bom exemplo. O que caracteriza a contemporaneidade não é, portanto, a circulação de bens simbólicos, mas a grande me- 
diação, resultado da tecnologia, que se interpôs nessa circulação: os meios de comunicação, os quais permitem a formação de redes planetárias, nas quais circulam valores, que atendem a interesses determinados. Esse é um dos aspectos da ideologia.

Segundo Chauí,

“a ideologia é um conjunto lógico, sistemático e coerente de representações (idéias e valores) e de normas ou regras (de conduta) que indicam e prescrevem aos membros da sociedade o que devem pensar, o que devem valorizar, o que devem sentir e como devem sentir, o que devem fazer e como devem fazer. Ela é, portanto, um corpo explicativo (representações) e prático (normas, regras, preceitos) de caráter prescritivo, normativo, regulador, cuja função é dar aos membros de uma sociedade dividida em classes uma explicação racional para as diferenças sociais, políticas e culturais, sem jamais atribuir tais diferenças à divisão da sociedade em classes, a partir das divisões na esfera da produção. Pelo contrário, a função da ideologia é a de apagar as diferenças como as de classes e de fornecer aos membros da sociedade o sentimento da identidade social, encontrando certos referenciais identificadores de todos e para todos, como, por exemplo, a Humanidade, a Liberdade, a Igualdade, a Nação ou o Estado" (8)

No momento em que se fala tanto da ressignificação do papel da escola e do professor, a partir da intervenção da tecnologia, é fundamental nos aproximarmos das questões referentes à ideologia que circula nos meios de comunicação, nas redes planetárias e, verificando essa circulação, procurar saber como a ideologia opera nessa realidade.

\section{Ideologia e construção de sentido}

Ao tratar de ideologia, não podemos prescindir de buscar o lugar social da produção das formas simbólicas que circulam nas redes, o lugar social dos receptores dessas formas e as formações sociais nas quais ambos se encontram.

Segundo Thompson,

"o conceito de ideologia pode ser usado para se referir às maneiras como o sentido (significado) serve, em circunstâncias particulares, para estabelecer e sustentar relações de poder que são sistematicamente assimétricas - que eu chamarei de 'relações de dominação’. Ideologia, falando de uma maneira mais ampla, é sentido a serviço do poder. Conseqüentemente, o estudo da ideologia exige que investiguemos as maneiras como o sentido é construído e usado pelas formas simbólicas de vários tipos, desde as falas lingüísticas cotidianas até às imagens e aos textos complexos" (9).

A construção do sentido das formas simbólicas está diretamente relacionada à formação socioeconômica. Eé só aí que podemos verificar em que direção elas estão, predominantemente, sendo usadas: se na manutenção do status quo, servindo apenas para perpetuar as relações de poder, se na sua modificação, trilhando o caminho da mudança dessas relações de poder. Afinal, diz Thompson, “as formas simbólicas, ou sistemas simbólicos, não são ideológicos em si mesmos: se eles são ideológicos, e o quanto são ideológicos, depende das maneiras como eles são usados e entendidos em contextos sociais específicos"(10).

Neste momento em que o mundo está desfraldado em um número enorme de tempos históricos e culturais, neste momento em que as produções, sobretudo no âmbito da televisão, viajam pelo mundo e atingem praticamente todas as sociedades, nesses tempos/espaços díspares, muitas vezes em tempo real, pode-se perceber a divulgação, sob forma prescritiva, desse conjunto de idéias e valores, de normas ou de regras, que procuram dar suas próprias explicações para as diferenças sociais, políticas e culturais, objetivando o apagamento dessas diferenças, como lembra Chauí. Manter, por exemplo, uma emissora de televisão no ar durante algumas horas do dia, e
8 Idem, ibidem, pp. 113-4

9 John B. Thompson, Ideologia e Cultura Moderna. Teoria Social Crítica na Era dos Meios de Comunicação de Massa Petrópolis,Vozes, 1995, p

10 ldem, ibidem, p. 17. Ogrifoé nosso. Parece-nos importante destacar a importância do "entendimento", da interpretação da recepção 
mais ainda quando se trata de uma grade de programação para 24 horas, é tarefa hercúlea que exige um trânsito muito grande de produções, o que aponta para a permanência desse procedimento.

Não se nega que há diversidade no pólo da produção e que é mais extensa ainda a diversidade do entendimento, da interpretação da recepção dessas representações.

Cabe à escola - e aí um dos aspectos da ressignificação de seu papel - desvelar como opera a ideologia, ensinar a ler adequadamente as formas simbólicas que circulam na mídia, conformando a realidade.

\section{Ideologia e cotidiano}

É no cotidiano que se jogam as modificações ou manutenção da ideologia construída. Éno cotidiano, onde as atitudes, os fazeres se dão num clima de relaxamento maior, que se torna mais fácil o jogo de influências. Como lembra Agnes Heller, na vida cotidiana o homem coloca " "em funcionamento' todos os seus sentidos, todas as suas capacidades intelectuais, suas habilidades manipulativas, seus sentimentos, paixões, idéias, ideologias". E exatamente por isso "nenhuma delas pode realizar-se, nem de longe, em toda sua intensidade" (11).

Por isso, as manifestações de poder que mais atingem as pessoas são aquelas que regem as atividades cotidianas. $\mathrm{Na}$ produção dos meios de comunicação, em qualquer gênero, utiliza-se sobremaneira do cotidiano.

Nesse cotidiano, que inclui o trabalho e a vida privada, o lazer, a vida social organizada e o intercâmbio, o sujeito amadurece. Esse processo de amadurecimento passa por grupos (família, escola). São esses grupos que estabelecem a mediação entre o indivíduo e os costumes, as normas e a ética da sociedade. Ressalta-se, desse modo, o papel da escola, grupo privilegiado de mediação. Mas, lembra Agnes Heller, “o homem não ingressa nas fileiras dos adultos, nem as normas assimiladas ganham 'valor', a não ser quando essas comunicam realmente ao indivíduo os valores das integrações maiores, quando o indivíduo-saindo do grupo (por exemplo, da família) - é capaz de se manter autonomamente no mundo das integrações maiores, de orientar-se em situações que já não possuem a dimensão do grupo humano comunitário, de mover-se no ambiente da sociedade em geral e, além disso, de mover por sua vez. esse mesmo ambiente" (12).

À escola compete, portanto, capacitaro aluno para não apenas "mover-se na sociedade", seguindo "o que e como deve sentir e fazer", mas, sobretudo, ter condições de mover, de modificar esse mesmo ambiente, o que só pode acontecer a partir da ressignificação dos sentidos, da reconstrução das "normas e regras" prescritas.

\section{Circulação das formas simbólicas}

As formas simbólicas, as representações circulam entre sujeitos, entre os quais obrigatoriamente haverá uma interseção, maior ou menor, de interpretação, a qual lhes permite compreender o que vêem, ouvem ou leem: permite-lhes comunicar-se. Ou seja, as formas simbólicas emergem do "real" e são constitutivas desse "real". Assim, por exemplo: quando uma telenovela é apresentada, ela estará sendo vista por um grande número de pessoas pertencentes a diferentes regiões geográficas, com culturas específicas. As formas simbólicas que circulam na telenovela são reconstruídas e interpretadas, nessas várias culturas, como "outras" formas simbólicas, de modo que possam estar vinculadas àquela cultura, de modo que pertençam àquele universo, garantindo-se o mínimo de interseção. Em outras palavras: o próprio receptor reconstrói o pólo da emissão. Evidentemente, e com mais força, o mesmo se dá quando qualquer programa de mídia produzido em um determinado país circula em outro, ou, continuando com a telenovela brasileira, quando ela é apresen- 


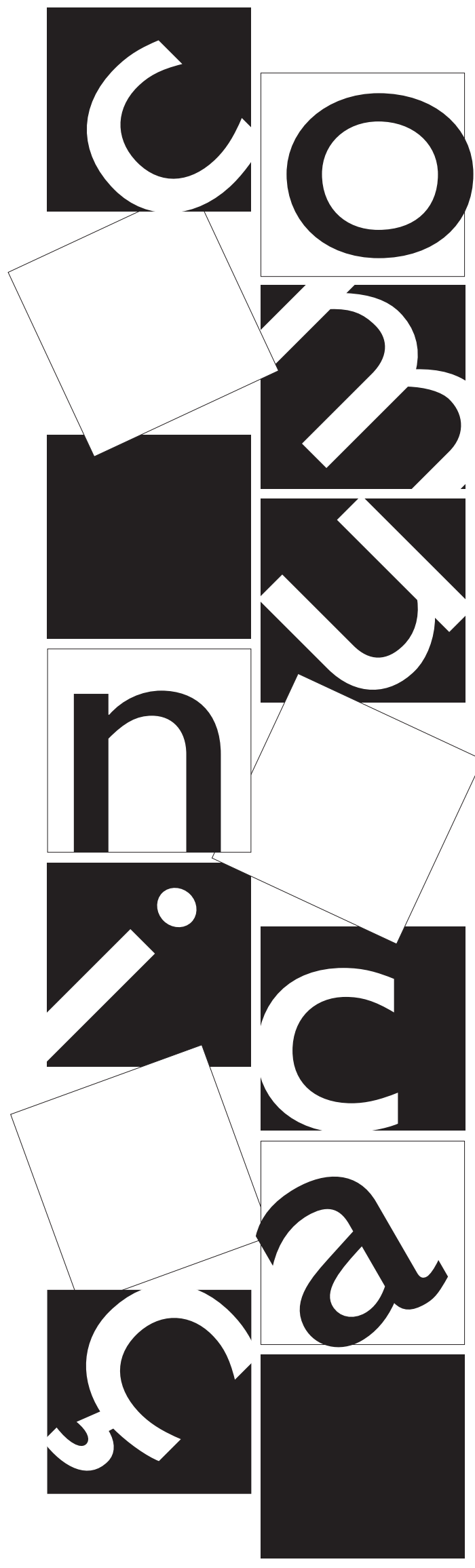

tada em países tão diferentes do nosso, como é o caso, para citar apenas um, de Escrava Isaura, na China (país que, por sua vez, se constitui de um número imenso de culturas). Há os que afirmam que o grande sucesso dessa novela em todo o mundo se deve ao fato de ela ser um hino à liberdade, uma denúncia da opressão. Será?

Qualquer que seja a produção dos meios de comunicação, a circulação das formas simbólicas constitui a grande mediação que se constata na cultura moderna, ou seja, a "midiação" da cultura moderna, caracterizada, no dizer de Thompson, pela "proliferação rápida de instituições e meios de comunicação de massa e o crescimento de redes de transmissão através das quais formas simbólicas mercantilizadas se tornaram acessíveis a um grupo cada vez maior de receptores" (13).

Há um rompimento, um distanciamento entre o enunciador/emissor e o enunciatário/ receptor. A interação desses dois pólos se dá “de outro modo", em “outro lugar”. E isso cria novas relações sociais, novos comportamentos culturais. Ou, como diz Martín-Barbero (14), “enquanto o cinema catalisava a 'experiência da multidão', pois era em multidão que os cidadãos exerciam seu direito à cidade, o que agora a televisão catalisa é, pelo contrário, a 'experiência doméstica' e domesticada, pois é 'a partir da casa' que as pessoas exercem agora, cotidianamente, sua participação na cidade". A propósito, uma propaganda da Starmedia, veiculada até recentemente, afirmava, com imagens: "não é preciso ir para estar".

Nesse contexto, o que vemos é o crescimento célere de redes de transmissão, a formação de conglomerados no campo dos meios de comunicação, fazendo circular essas formas simbólicas, as quais se infiltram nas culturas, mediando-as. $\mathrm{Na}$ verdade, o desenvolvimento dos meios de comunicação de massa e seu correspondente papel de mediadores da cultura, divulgadores de ideologia, se dá juntamente com o desenvolvimento do capitalismo industrial e com o nascimento do Estado moderno e suas formas de participação política.

13 John B. Thompson, Ideologia e Cultura Moderna, op. cit., p. 21.

14 Jesús Martín-Barbero, "Cidade Virtual: Novos Cenários da Comunicação", in Comunicação \& Educação, no 11, São Paulo, CCA-ECA-USP; Moderna, jan.abr./1998, p. 64. 
Hoje, na etapa que Jameson (15) chama de “capitalismo tardio", eles se colocam como centrais na construção do chamado pensamento único, que serve para sustentar o quase falido projeto neoliberal e apontar caminhos para sua mudança, sem perda da hegemonia pelos que detêm o poder.

Assim, podemos verificar a importância dos meios de comunicação para a discussão da ideologia. Com eles, a produção e circulação de formas simbólicas se dá não apenas de maneira rápida, como também extrapola o espaço e o tempo, superando o contexto social no qual são produzidas, afetando pessoas em lugares distantes e em culturas diferentes. Desse modo eles se tornaram básicos para a operacionalização da ideologia, entendida como corpo explicativo e prático de caráter prescritivo, como diz Chauí, como produção de sentido dos bens simbólicos, acrescendo-se Thompson, ou como base das relações imagéticas.

Não se conclua, porém, que os meios de comunicação representam o único fator de transmissão da ideologia nas sociedades modernas. Embora se constituam em fator privilegiado, pois intervêm em todas as esferas, a operacionalização da ideologia também se dá nas falas despreocupadas do cotidiano, arena onde normalmente se joga o futuro, e em todos os discursos sociais nos quais se banham os sujeitos. Algumas instituições, evidentemente, se destacam: entre elas, a escola.

Consideramos, por isso, de extrema importância a discussão das questões referentes à ideologia, neste momento em que a escola, instância fundamental de socialização, lugar privilegiado dos jogos do cotidiano, imbrica-se com os meios de comunicação e se abre para os usos da tecnologia em seus processos. Se por um lado a comunicação de massa se tornou um fator fundamental de transmissão de ideologia na sociedade moderna, por outro, é importante não se esquecer de que a ideologia opera numa grande variedade de contextos da vida cotidiana: das conversas entre amigos à solenidade das agências de educação.

\section{RECEPÇÃO: NOVA PERSPECTIVA NOS ESTUDOS DE COMUNICAÇÃO}

Conta-se que um intelectual famoso foi dar uma conferência dedicada aos aspectos matemáticos do corte da roupa. O tema atraiu um público inesperado: estilistas, mulheres interessadas em moda, etc. Mas a primeira frase do conferencista - "Suponhamos, para simplificar, que o corpo humano tenha a forma de esfera" - afugentou-os. Ficaram na sala apenas os matemáticos, para quem era dirigida a conferência. Para eles nada havia de assombroso naquela frase. Desse modo, selecionou-se o auditório (16).

Quisemos começar contando esse caso para deixar registradas duas chaves de leitura: a) quando tratamos de recepção, estamos tratando também do outro pólo: o da emissão. Só o encontro dos dois constitui a comunicação. Por isso, é preferível falar sempre em campo da comunicação. Os estudos de recepção não são um "lado novo" da comunicação: trata-se apenas de uma nova perspectiva desses estudos, a qual vem se desenvolvendo nas últimas décadas; b) quando se fala em comunicação, não estamos tratando apenas daquela veiculada pelos suportes tecnológicos (chamados meios de comunicação, mídia), embora os consideremos de extrema importância na atualidade, configurando-se, inclusive, como destacados construtores de realidades. Comunicação é interação entre sujeitos que, para tanto, podem utilizar-se predominantemente - e às vezes tão-somente - do mais democrático de todos os suportes: o aparelho fonador. As feiras, a literatura de cordel, o circo, o teatro, o folhetim, o carnaval, entre muitas outras, configuram-se nessa modalidade de comunicação e constituem as matrizes históricas dos produtos dos meios de comunicação, tal qual os conhecemos hoje.

Para que haja comunicação, é preciso que os interlocutores tenham uma "memória" comum, participem de uma mesma cultura. Isso porque a comunicação se 
manifesta nos discursos e os discursos que circulam na sociedade se constituem a partir da intertextualidade, que Chabrol conceitua assim: "Trata-se de todos os fenômenos de citação, referência, retomada, empréstimo, tranformação, derivação, desvio, inversão entre textos, contemporâneos ou não, na esfera dos discursos sociais, quer seja no interior de um mesmo domínio, quer seja entre suportes midiáticos ou ainda entre domínios diversos (mídias, literatura, cinema, publicidade, etc.)"(17).

Desse modo, vemos que todo discurso se constitui a partir de sua inter-relação com os outros e só assim poderá ser interpretado. Bakhtin, um dos mais importantes teóricos da linguagem, tratando da linguagem verbal, afirma que a verdadeira substância da língua é a interação verbal (e não o sistema abstrato de formas lingüísticas). Essa realidade fundamental da língua, segundo o autor, manifesta-se no diálogo: “Pode-se compreender a palavra 'diálogo' não apenas como a comunicação, em voz alta, de duas pessoas colocadas face a face, mas toda comunicação verbal, de qualquer tipo que seja"(18). E continua, falando sobre o discurso:

"Ele responde a alguma coisa, refuta, confirma, antecipa as respostas e objeções potenciais, procura apoio etc. Qualquer enunciação, por mais significativa e completa que seja, constitui apenas uma fração de uma corrente de comunicação verbal ininterrupta (concernente à vida cotidiana, à literatura, ao conhecimento, à política, etc.). Mas essa comunicação verbal ininterrupta constitui, por sua vez, apenas um momento na evolução contínua, em todas as direções, de um grupo social determinado"(19).

Cada discurso, quer use apenas a voz ou a tecnologia mais avançada - satélite, por exemplo -, é, na verdade, a atualização de um processo de interlocução entre vários discursos, manifestação de diálogos, entre os mais diversos gêneros e até entre as mais diferentes épocas. Assim, tanto o pólo da emissão, aquele que produz o programa que escreve o jornal, quanto o pólo da recepção, aquele que vê, ouve ou lê o produto, só têm sua completude sacramentada, só significam pela via desse diálogo. Trata-se de diálogo que tem como cenário uma determinada cultura, e sem o qual não haveria (não se poderiam constituir) a telenovela, o noticiário, a música, etc. Não haveria, inclusive, os programas policiais, no rádio e na televisão, que causam tanta polêmica. Sem esse diálogo com a cultura, com as referências culturais, de ambos os pólos, com a cultura e entre eles mesmos, teríamos uma parcialidade que impediria a constituição de sentido.

Toda a produção dos meios de comunicação está, portanto, marcada pelos processos de interpretação-recepção de outros discursos (midiáticos ou não) efetuados pelo seu produtor. Existirá sempre um diálogo, uma interlocução, ainda que mediata, indeterminada, até mesmo tênue, como lembra Chabrol.

São as referências que vão traçando percursos de leitura. Por isso dizemos que a comunicação está imersa na cultura. É uma prática cultural que produz significados, ou seja, a partir do que está e já é naquela cultura, ressemantizam-se os significados em cada ato de comunicação. Implica sempre, como vimos, emissão e recepção, resultando na construção de sentidos novos, renovados - ou mesmos sentidos reconfigurados - , produzidos nesse encontro.

Por isso se fala em campo da comunicação. Cada discurso, cada programa dos meios de comunicação será produzido e interpretado, entendido a partir das referências de sua cultura. E ainda mais: nos processos de criação de sentidos, os produtores e os receptores, na sua condição de atores sociais, mobilizam fatores até inusitados. Podem utilizar-se, por exemplo, de certas normas e padrões, considerados arcaicos, mas que estão presentes na memória coletiva, revivendo-os em determinadas situações contemporâneas.

Portanto, o significado da comunicação, as significações dos produtos culturais, incluindo os produtos dos meios de comu-
17 Claude Chabrol, "Le Lecteur: Fantôme ou Realité? Étude des Processus de Réception" |"O Leitor: Fantasma ou Realidade? Estudo dos Processos de Recepcão"l, in Patrick Charaudea La Presse: Produit, Production, Réception, Paris, Didier, 1988 p. 165

18 Mikhail Bakhtin, Marxismo Filosofia da Linguagem, $4^{a}$ ed São Paulo, Hucitec, 1988 123 e segs.

19 ldem, ibidem, p. 123 Igrifos nossos). 
nicação, relacionam-se com o cotidiano do sujeito receptor, com suas práticas culturais, com as marcas que influenciam seu modo de ver e praticar a realidade, e que são aquelas que lhe dão segurança necessária para estruturar, organizar/reorganizar a percepção dessa realidade, reconstruindoa, com destaques ou apagamentos, de acordo com sua cultura. Essas práticas culturais constituem as mediações, que interferem em todo o processo comunicacional, balizando-o.

Para Martín-Barbero, as mediações

“são esse 'lugar' a partir do qual é possível compreender a interação entre o espaço da produção e o da recepção: o que se produz na televisão não atende unicamente às necessidades do sistema industrial e a estratégias comerciais, mas também a exigências que vêm da trama cultural e dos modos de ver. Estamos afirmando que a televisão nãofunciona sem assumir - e, ao assumir, legitimar - as demandas que vêm dos grupos receptores; mas, por sua vez, não pode legitimar essas demandas sem ressignificálas em função do discurso social hegemônico"(20).

Desse modo, podemos falar de um autor e de um receptor "previsíveis" naquela cultura. Podemos até dizer que, na verdade, os "receptores ideais" "fazem parte" do produto emitido. Mas esses "receptores ideais" não se confundem com o receptor pessoa (se assim fosse, todos os produtos dos meios de comunicação teriam sempre êxito absoluto). O receptor-sujeito vai ressignificar o que ouve, vê ou lê, apropriar-se daquilo a partir de sua cultura, do universo de sua classe, para incorporar ou não a suas práticas.

Nesse caminho podemos distinguir os estudos de recepção dos estudos de consumo. O simples fato de uma campanha de chocolate ter efetivamente possibilitado a venda de um número maior de chocolates não indica que houve recepção como a estamos entendendo. Indica apenas que houve apropriação, transitória, de alguma coisa. E estaríamos aí no campo do consumo.
Logo, não é pelo fato de uma campanha publicitária ter obtido sucesso de vendas que poderemos afirmar que o sujeito receptor ressignificou comportamentos culturais, incorporando-os à sua prática. Recepção é um processo lento e contínuo e não se mede apenas pela quantidade.

Os receptores tornam-se co-produtores do produto cultural. São eles que o (re)vestem de significado, possibilitando a atualização de leituras, o rompimento de caminhos preestabelecidos de significados, a abertura de trilhas que poderão desaguar em reformulações culturais.

A recepção, como ato cultural, desempenha importante papel na construção da realidade social. Daí a importância de seu estudo. Através destes estudos podemos descobrir quais são os processos reais que resultam do encontro dos discursos dos meios de comunicação apropriados (transitoriamente) ou incorporados (com permanência na cultura) pelos sujeitos-receptores imersos em suas práticas culturais.

Os estudos de recepção estão preocupados com as características socioculturais dos receptores. Desse modo, o foco se desloca para as práticas sociais e culturais mais amplas, nas quais eles estão integrados. É nesse espaço que se estudará a ressignificação que os receptores produzem com relação aos produtos dos meios de comunicação.

Segundo Martín-Barbero,

"abre-se ao debate um novo horizonte de problemas, no qual estão redefinidos os sentidos tanto da cultura quanto da política, e do qual a problemática da comunicação não participa apenas a título temático e quantitativo - os enormes interesses econômicos que movem as empresas de comunicação - mas também qualitativo: na redefinição da cultura, é fundamental $a$ compreensão de sua natureza comunicati$v a$. Isto é, seu caráter de processo produtor de significações e não de mera circulação de informações, no qual o receptor, portanto, não é um simples decodificador daquilo que o emissor depositou na mensagem, mas também um produtor" (21). 
Nessa postura, o papel da escola redefine-se: não basta falar em educação para os meios ou em leitura crítica dos meios, como se os meios de comunicação fossem uma realidade externa, "de fora". A escola precisa, portanto, não apenas problematizar o conteúdo dos meios, mostrando a interface desse conteúdo com os valores hegemônicos da sociedade e com os interesses que aí residem (ainda que se trate de uma etapa indispensável). Não basta, também, discutir as propostas dos programas midiáticos em confronto com as propostas culturais dos receptores, desvelando as convergências e divergências.

Mais que isso: é preciso falar, agora, dessa construção de sentidos sociais que se dá no encontro produtos midiáticos/receptores, no bojo da construção das práticas culturais, da construção da cidadania. É desse lugar que devemos nos relacionar com eles. E é esse o lugar de onde temos que esclarecer qual cidadania nos interessa, parece-nos sempre oportuno reiterar.

\section{CONSIDERAÇÕES FINAIS}

Muitas outras temáticas compõem o campo da comunicação/educação, o qual se constitui a partir do campo da comunicação. Para estudá-lo, é preciso estabelecer um diálogo mais amplo, com mais saberes. Sem transdisciplinaridade, o estudo da comunicação não ocorre. "Tentar desvencilhar-se delas [as disciplinas], identificando a comunicação a uma disciplina, é reduzir o campo a uma parcela que, por mais rica que seja, não poderá nunca deixar de ser um empobrecimento deformante e uma usurpação"(22).

A escola, ressignificada, é chamada mais uma vez, e sempre, para, no bojo dessa realidade, apontar caminhos de democratização. Um desses caminhos passa pela distinção entre a informação, fragmentada, e o conhecimento, totalidade que "inclui a condição de ser capaz de trazer à superfície o que é ainda virtual naquele domínio. Prevê ter claro que o virtual de um domínio nada mais é que o resultado da interdiscursividade de todos os domínios, possível naquela formação social; que os diversos fenômenos da vida são concatenados em referência à sociedade como um todo. Para tanto, as informações fragmentadas não são suficientes" (23). E essa inter-relação só é possível pela transdisciplinaridade.

No campo da comunicação/educação circulam essas

"situações novas que encontraram sua expressão teórica mais avançada em uma compreensão da cultura como configuração histórica dos processos e das práticas comunicativas. Essas que necessitam, mais do que nunca, articular os saberes quantitativos a um conhecimento qualitativo capaz de decifrar a produção comunicativa de sentido, toda a trama de discursos que ela mobiliza, de subjetividades e de contextos, em um mundo de tecnologias midiáticas, cada dia mais densamente incorporadas à cotidianidade dos sujeitos e cada dia mais descaradamente excludentes dos direitos das maiorias à voz e ao grito, à palavra e à canção" (24).

Eis a importância do campo comunicação/educação. Na disputa estabelecida entre meios de comunicação $x$ escola e família - não é possível haver ganhadores e perdedores. Evidencia-se, cada vez mais, um intercâmbio das agências de socialização na construção da cidadania.
22 Jesús Martín-Barbero, "Prefácio", in M. A. Baccega, A Comunicação e Linguagem. Discursos e Ciência, São Paulo, Moderna, 1998.

23 M. A. Baccega, Comunicação e Linguagem. Discursos e Ciência, op. cit., p. 112

24 J. Martín-Barbero, "Prefácio" op. cit. 